\title{
Evaluating and using stable-isotope analysis to infer diet composition and foraging ecology of Adélie penguins Pygoscelis adeliae
}

\author{
Megan Tierney ${ }^{1, *}$, Colin Southwell ${ }^{2}$, Louise M. Emmerson ${ }^{2}$, Mark A. Hindell ${ }^{1}$ \\ ${ }^{1}$ Antarctic Wildlife Research Unit, School of Zoology/Antarctic Climate and Ecosystems Cooperative Research Centre, \\ University of Tasmania, Private Bag 05, Hobart, Tasmania 7001, Australia \\ ${ }^{2}$ Department of the Environment and Water, Australian Antarctic Division, 203 Channel Highway, Kingston, Tasmania 7050, Australia
}

\begin{abstract}
We investigated whether diet composition determined from stable-isotope analysis (SIA) was similar to that determined from stomach content analysis for Adélie penguins Pygoscelis adeliae. We also used SIA to compare diet composition of adults and chicks and to evaluate intra- and inter-annual variations in diet and foraging ecology of adults over 2 consecutive breeding seasons (2001-2002 and 2002-2003) and 3 consecutive moulting seasons (2000-2001 to 2002-2003). Diet determined from SIA closely mirrored that determined from stomach contents at the broad taxonomic level (i.e. fish vs. krill). Diet composition did not differ between adults and chicks, but the more depleted $\delta^{13} \mathrm{C}$ values of adult blood suggest that adults may forage for themselves and provide their chicks with food from different locations. Adult $\delta^{13} \mathrm{C}$ signatures varied intra-annually with the most depleted values measured during the arrival period, followed by incubation, guard and then crèche. $\delta^{15} \mathrm{~N}$ analyses indicated that krill and fish were being consumed prior to arrival at the breeding colonies and during incubation foraging trips, while the primary prey consumed during chick-rearing differed between years. $\delta^{15} \mathrm{~N}$ did not vary in the pre-moult periods, with adult diet consisting primarily of krill in all 3 years, but the depleted $\delta^{13} \mathrm{C}$ signatures of feathers in 2000-2001 indicated that adults foraged farther from shore in that year. This study demonstrates that SIA is useful for monitoring diet and foraging areas of Adélie penguins at broad resolutions, particularly during periods when it is not possible to use conventional dietary techniques, although penguins may be most vulnerable to impacts such as commercial fishing during these periods as well.
\end{abstract}

KEY WORDS: Stable nitrogen $\cdot$ Stable carbon $\cdot$ Whole blood $\cdot$ Feathers $\cdot$ Antarctica

Resale or republication not permitted without written consent of the publisher

\section{INTRODUCTION}

Studies estimating the diet of seabirds have traditionally relied upon the direct analysis of stomach contents collected from either deceased or sacrificed animals (e.g. Furness et al. 1984) or through stomach lavage (e.g. Clarke et al. 1998, Berrow \& Croxall 1999). Stomach contents can provide detailed taxonomic and quantitative data (Hobson \& Clark 1992a, Michener \& Schell 1994), but a number of limitations and biases are associated with this technique (see Michener \& Schell 1994), not the least of which is that these samples are biased towards the most recent feeding events and towards biota (or remnants) that are not easily digested. A particular disadvantage of stomach content analysis is that use of the technique and inferences that can be made about diet from it are restricted to periods when birds are both accessible and have full stomachs. Consequently, most seabird diet data is biased towards the chick-rearing period when adults bring food ashore for their chicks (Hobson 1993, Quillfeldt et al. 2005, Steel 2005). It is also difficult, if not impossible, to separate chick and adult diets using stomach content analysis, which has often led to the assumption that what adults deliver to chicks is what they consume for themselves. However, prey can vary 
spatially and temporally (e.g. Pauly et al. 2000), and resources required by chicks for growth and survival may differ from what adults need for self-maintenance (Klasing 1998). Differences in diet between adults and chicks, or for adults outside the chick-rearing period, influence resource allocation models or conservation and management strategies.

A key question for dietary studies regards the methods that could be used to qualify and quantify the consumption of prey by seabirds. Over the past $25 \mathrm{yr}$, stable-isotope analysis (SIA) has emerged as a powerful alternative to more direct methods such as stomach sampling and observation. Amongst other applications, SIA has been used in marine studies to provide information on feeding ecology (e.g. Thompson \& Furness 1995, Quillfeldt et al. 2005), and the development of isotopic mixing models (Hobson 1993, Phillips \& Gregg 2001) has meant that SIA could be used to provide quantitative data on diet composition (e.g. Forero et al. 2002). Stable isotopes are used in dietary studies because the isotopic ratios of carbon $\left({ }^{13} \mathrm{C} /{ }^{12} \mathrm{C}\right)$ and nitrogen $\left({ }^{15} \mathrm{~N} /{ }^{14} \mathrm{~N}\right)$ in the tissues of consumers reflect those of its dietary components assimilated in a reliable and predictable manner (DeNiro \& Epstein 1978, 1981, Hobson \& Clark 1992a,b). Consumers preferentially excrete the lighter isotope and retain the heavier one, so their tissues become 'enriched' compared with their diet (Owens 1987). Nitrogen-15 $\left(\delta^{15} \mathrm{~N}\right)$ concentrations in tissues of marine consumers typically increase by 2 to $5 \%$ per trophic level and can be used to estimate trophic position (Owens 1987, Hobson \& Welch 1992). Carbon-13 $\left(\delta^{13} \mathrm{C}\right)$ concentrations increase by only $\sim 0.8$ to $2 \%$ per trophic level (DeNiro \& Epstein 1978, Hobson \& Welch 1992, McCutchan et al. 2003) and reflect the source of carbon at the base of their food chain (Kelly 2000). Because $\delta^{13} \mathrm{C}$ concentrations of pelagic phytoplankton are more depleted than those of many inshore and benthic phytoplankton, $\delta^{13} \mathrm{C}$ values in consumer tissues can be used to infer foraging location, differentiating between inshore vs. offshore and benthic vs. pelagic feeding (see Kelly 2000, Cherel \& Hobson 2007).

Predator diet can be inferred over different time scales depending on the tissue sampled (Hobson \& Clark 1993) because different animal tissues have different rates of isotopic turnover (Hobson \& Clark 1992a, Cherel et al. 2005a), which may be related to the rate of protein turnover (Carleton \& de Rio 2005). For example, whole blood reflects the diet integrated over a period of 3 to $4 \mathrm{wk}$, while tissues that become metabolically inert after growth, such as feathers, can be used to reflect diet over the period in which they were grown (Hobson \& Clark 1992a, Bearhop et al. 2002). Whole blood and feathers are particularly advantageous for SIA dietary studies because they can be sampled non-destructively, serial samples can be collected from the same individual, and they can be used to examine diet in discrete temporal windows, including periods outside the limited sampling seasons of conventional methods.

Most studies investigating the degree to which stable isotopes in animal tissues reflect a known diet have used captive animals (e.g. Hobson \& Clark 1992b, Cherel et al. 2005b). Differences in rates of protein synthesis and catabolism, however, can influence the rate of isotopic turnover and assimilation (Carleton \& de Rio 2005). These can vary between captive and wild populations due to factors such as body size, activity or nutritional stress (Nagy 1987). Few studies, (although see Ainley et al. 2003) have compared how well the diet of a wild population determined by stable isotopes reflects a diet collected and analyzed simultaneously by direct methods.

In this paper we determine whether the analysis of stable isotopes in whole blood and feathers from a wild population of Adélie penguins Pygoscelis adeliae can be used to assess their diet. Adélie penguins are important predators of high biomass Southern Ocean species, including krill and several species of fish (Ainley 2002). Improved knowledge of the spatial and temporal variability in their diet can contribute to a better understanding of ecosystem structure and function and to the management of living resources in the Southern Ocean. With regard to management, the Convention for the Conservation of Antarctic Marine Living Resources (CCAMLR) has selected Adélie penguins as an indicator species, and their consumption of krill as an indicator parameter, for managing the krill fishery (Constable et al. 2000). CCAMLR has assessed Adélie penguin diet through analysis of stomach contents during the chick rearing period (SCCAMLR 1997), with particular interest in the broad taxonomic range of dietary components, especially what proportion of their diet is made up of Euphausia superba as opposed to other components, such as fish. The assessment of results from stomach content analysis compared with alternative techniques such as SIA could have important ramifications for the methodology used in ecosystem monitoring programs as well as for other investigations of Adélie penguin diet. We specifically investigated (1) whether diet composition determined from $\delta^{13} \mathrm{C}$ and $\delta^{15} \mathrm{~N}$ isotopes is similar to that determined from stomach content analysis, (2) whether SIA can detect differences in diet composition between adults and chicks, and whether any of these differences are reflected in the foraging behaviour of adults as inferred from SIA, and (3) we examined the intra- and inter-annual variation in diet composition and foraging location throughout their annual cycle. 


\section{MATERIALS AND METHODS}

Annual cycle of Adélie penguins. The annual life cycle of Adélie penguins has been described by several authors (see Ainley 2002 and references therein). They return to their breeding colonies in mid-October each year after over-wintering at sea in the Antarctic pack ice. Their breeding cycle can be divided into 3 distinct stages: arrival (mid-October to mid-November), incubation (mid-November to mid-late-December) and chick rearing, the latter of which can be further divided into guard (mid-December to early-midJanuary) and crèche (early-mid-January to mid-February) periods. Chicks fledge in early-mid-February. At the end of chick-rearing, adults forage at sea (midFebruary to mid-March) to build up body reserves for their annual moult. Over the 3 to 4 wk moulting period (mid-March to early-April) the birds are restricted to land, and hence must fast while they replace their entire set of feathers before returning to sea for the winter.

Study area and sample collection. Stomach contents (adults only) and blood samples (adults and chicks) were collected from Adélie penguins during each breeding stage from colonies in the Mawson station (Australia) region of MacRobertson Land, East Antarctica $\left(67^{\circ} 33^{\prime}\right.$ to $67^{\circ} 35^{\prime} \mathrm{S}, 62^{\circ} 55^{\prime}$ to $62^{\circ} 49^{\prime}$ E) over 2 consecutive austral summers (2001-2002 and 2002-2003). Feathers from adult birds were collected during the arrival and incubation periods of 2001-2002, 20022003 and 2003-2004. Because feathers are metabolically inert after growth (Hobson \& Clark 1992a), those collected at this time potentially reflect food consumed during the pre-moult foraging trips in the year prior to collection, i.e. late-February to mid-March, 20002001, 2001-2002 and 2002-2003. Because Adélie penguin breeding and moulting seasons span the austral summer over split-years, we hereafter refer to each season by its initial calendar year.

Stomach contents: Stomach contents were collected from adult birds using water offloading (Wilson 1984) following the CCAMLR Ecosystem Monitoring Program (CEMP) Standard Methods (SC-CAMLR 1997) and stored in $70 \%$ ethanol until analysis. Birds were only sampled during the guard and crèche stages, because stomachs of adults are generally empty during the arrival and incubation stages. A total of 30 and 37 adult birds were sampled during the 2001 and 2002 summers, respectively. The CEMP Standard Methods (SC-CAMLR 1997) were used to analyse samples. Each stomach sample was drained and excess liquid removed before being weighed to obtain total meal mass (wet weight). Samples were then sorted and prey species identified to the lowest taxonomic level possible. Generally, krill could be identified to species level (unless highly digested) and amphipods to family level. Fish remains were usually well digested and were not resolved further. The few squid beaks recovered were not identified. Each prey component was weighed and percent composition by wet mass calculated.

Blood, feathers and prey samples: Using a 21-gauge needle and syringe, up to $5 \mathrm{ml}$ of blood was collected from the jugular vein of a total of 75 adult birds in the 4 breeding stages during 2001 and 2002. Of these samples, 23 in 2001 and 13 in 2002 were from birds that had also had their stomach contents collected. Using a 21-gauge needle and syringe, up to $3 \mathrm{ml}$ of blood was collected from the medial meta-tarsal vein of a total of 40 chicks during the crèche periods of 2001 and 2002. Whole blood samples from adults and chicks were either stored frozen at $-20^{\circ} \mathrm{C}$ or kept in liquid nitrogen until analysis. Up to 3 feathers (representing the moulting periods of 2000, 2001 and 2002), were plucked from 31, 30 and 31 adult birds sampled in 2001, 2002 and 2003, respectively. Intact specimens of 9 whole adult Euphausia superba, the most common krill species eaten by Adélie penguins in the Mawson region, and 10 whole juvenile Trematomus newnesi, a commonly consumed fish (Clarke et al. 1998) were selected from the stomach contents of Adélie penguins to represent the krill and fish components of their diet for SIA. Prey samples were stored in ethanol until analysed.

Stable-isotope analysis. In preparation for SIA, lipids were removed from whole blood and prey samples using a 2:1 chloroform: $\mathrm{HCl}$ acid (5\%) solution. Although recent studies (e.g. Cherel et al. 2005b) show it is not necessary to remove lipids from avian whole blood for SIA, at the time our samples were analysed it was understood that the low $\delta^{13} \mathrm{C}$ content of lipids, in comparison to proteins, may influence the $\delta^{13} \mathrm{C}$ signature of blood samples (Kelly 2000), so they were removed. Feathers were cleaned of surface contaminants using a 2:1 chloroform:methanol rinse, air-dried, and then cut into small fragments. Prior to lipid removal, prey samples were rinsed successively in distilled water to remove ethanol, then freeze-dried and homogenized. Krill samples were not acidified to remove carbonates before isotopic analysis.

Carbon-13 and nitrogen-15 enrichment assays were performed on $1.5 \mathrm{mg}$ sub-samples of homogenized whole blood or feathers and on 25 to $100 \mathrm{mg}$ (krill) or 200 to $500 \mathrm{mg}$ (fish) sub-samples of homogenized prey tissue. Sub-samples were loaded into tin capsules and combusted at $1000^{\circ} \mathrm{C}$ in a Europa Scientific ANCA NT analyser. Resultant $\mathrm{CO}_{2}$ and $\mathrm{N}_{2}$ gases were analysed using an interfaced Europa 20:20 continuous-flow isotope ratio mass spectrometer (Europa Scientific), with unknowns separated by laboratory standards. Stable isotope abundances were expressed in $\delta$-notation as 
the deviation from standards in parts per thousand (\%o) according to the following equation:

$$
\delta X=\left[\left(R_{\text {sample }} / R_{\text {standard }}\right)-1\right] \times 1000
$$

where $X$ is ${ }^{13} \mathrm{C}$ or ${ }^{15} \mathrm{~N}$ and $R$ is the corresponding ratio of ${ }^{13} \mathrm{C} /{ }^{12} \mathrm{C}$ or ${ }^{15} \mathrm{~N} /{ }^{14} \mathrm{~N}$. $R_{\text {standard }}$ values were based on PeeDee Belemnite for ${ }^{13} \mathrm{C}$, or atmospheric nitrogen $\left(\mathrm{N}_{2}\right)$ in air for ${ }^{15} \mathrm{~N}$. Replicate measurements of laboratory standards showed measurement errors of $\pm 0.1 \%$ and $\pm 0.3 \%$ for stable carbon and nitrogen isotope measurements, respectively. Quality control samples were run before and after each sequence.

Statistical analysis. Differences in both $\delta^{13} \mathrm{C}$ and $\delta^{15} \mathrm{~N}$ blood isotope signatures between seasons and stages were investigated with 2-way ANOVAs for adults and chicks. A 1-way ANOVA was used to assess differences in feather isotopic signatures for the moult period between each season. Tukey Honestly Significant Difference (HSD) tests were used when post-hoc comparisons were required. Heterogenous variances associated with $\delta^{13} \mathrm{C}$ and $\delta^{15} \mathrm{~N}$ blood samples from adults could not be normalized by data transformations. Therefore, these samples were analysed using Linear Mixed Models (LMM) with Wald tests (Payne 2002) in place of the 2-way ANOVA $f$-tests. This more complex analysis, however, did not change the interpretations from a 2-way ANOVA, suggesting that the 2-way ANOVA was sufficiently robust to heterogeneity. Consequently, we only present the results of the 2-way ANOVA. None of the other data sets showed variances with serious deviations from homoscedacticity or assumptions of normality (Zar 1996). All analyses were conducted using the statistical package 'R' (www.r-project.org) or GenStat (VSNi) (Payne 2002).

Isotopic mixing model. We applied a single-isotope, 2-source linear mixing model derived by Hobson (1993) and Phillips \& Gregg (2001) to estimate the relative contribution of the 2 major prey items, krill and fish, to Adélie penguin diet. The sum of these 2 proportions from the mixing model equals $100 \%$. The proportion of each component was calculated by:

$$
P_{\mathrm{a}}=\left(D_{\mathrm{t}}-D_{\mathrm{b}}\right) /\left(D_{\mathrm{a}}-D_{\mathrm{b}}\right),
$$

where $P_{\mathrm{a}}$ is the proportion of the diet derived from source ' $\mathrm{a}$ '; $D_{\mathrm{t}}$ is the $\delta^{15} \mathrm{~N}$ value of the consumer blood; and $D_{\mathrm{a}}$ and $D_{\mathrm{b}}$ are the consumer blood $\delta^{15} \mathrm{~N}$ values corresponding to the exclusive diet of ' $a$ ' and ' $b$ ', respectively. The ' $a$ ' and ' $b$ ' terms are calculated as the isotopic value of the prey plus the diet-tissue discrimination factor $\left(\Delta_{\mathrm{dt}}\right)$ between the prey and consumer. Diet-tissue discrimination factors describe the way in which isotopic ratios from dietary sources fractionate as they are incorporated into different tissue types of the consumer (Hobson \& Clark 1992b). Equa- tions provided by Phillips \& Gregg (2001), which account for the observed variability in the isotopic signatures of the sources (i.e. prey items) as well as the mixture (i.e. the consumer), were used to calculate standard errors and $95 \%$ confidence intervals for each source component.

The $\delta^{15} \mathrm{~N}$ values derived in this study (see 'Results') for Euphausia superba and Trematomus newnesi were used to represent the krill (source 'a') and fish (source ' $b$ ') components, respectively. We assumed that diettissue fractionation factors $\left(\Delta_{\mathrm{dt}}\right)$ for $\delta^{15} \mathrm{~N}$ were $+2.7 \%$ and $+4.2 \%$ between lipid-free prey and penguin whole blood or feathers, respectively (Cherel et al. $2005 \mathrm{~b})$. We also assumed $\Delta_{\mathrm{dt}}$ were not affected by age (Hodum \& Hobson 2000).

Diet composition determined by an isotopic mixing model and stomach content analysis. Chick diet estimated from the isotopic mixing model described above was compared against that determined from stomach contents recovered from adults during the chickrearing period using $t$-tests. These analyses took account of the different number of replicates and variances associated with each mean (Steel \& Torrie 1960). On the strength of these results, we applied the mixing model, using both adult blood and feather isotopic data, to quantify the diet composition of adults in each of the breeding and moult stages. We also used the mixing model to compare the diet composition of adults and chicks in the crèche period. It should be noted that the stomach contents collected from adults at the end of the season, which had not been fed to chicks, and hence would not have been assimilated into their blood, were omitted from all analyses.

\section{RESULTS}

\section{Diet composition estimated from stomach contents}

Mean meal mass and diet composition of adult Adélie penguins during the guard and crèche periods of 2001 and 2002 are presented in Table 1. Meal mass was greater in 2001. Euphausia superba and fish were the primary prey items consumed in both years, comprising $>90 \%$ of the diet by mass. E. crystallorophias, amphipods, squid, rocks, shells and seaweed made up the remainder of the diet. Krill dominated the diet during both the guard and crèche periods of 2001, while fish dominated both stages in 2002. Frequencies of occurrence (\%FOO) calculations show that the major prey items were found in relatively equal proportions during both years. However, the frequency of krill in the diet decreased by $40 \%$ between 2001 and 2002, whereas fish occurred in almost all stomachs in both years. 


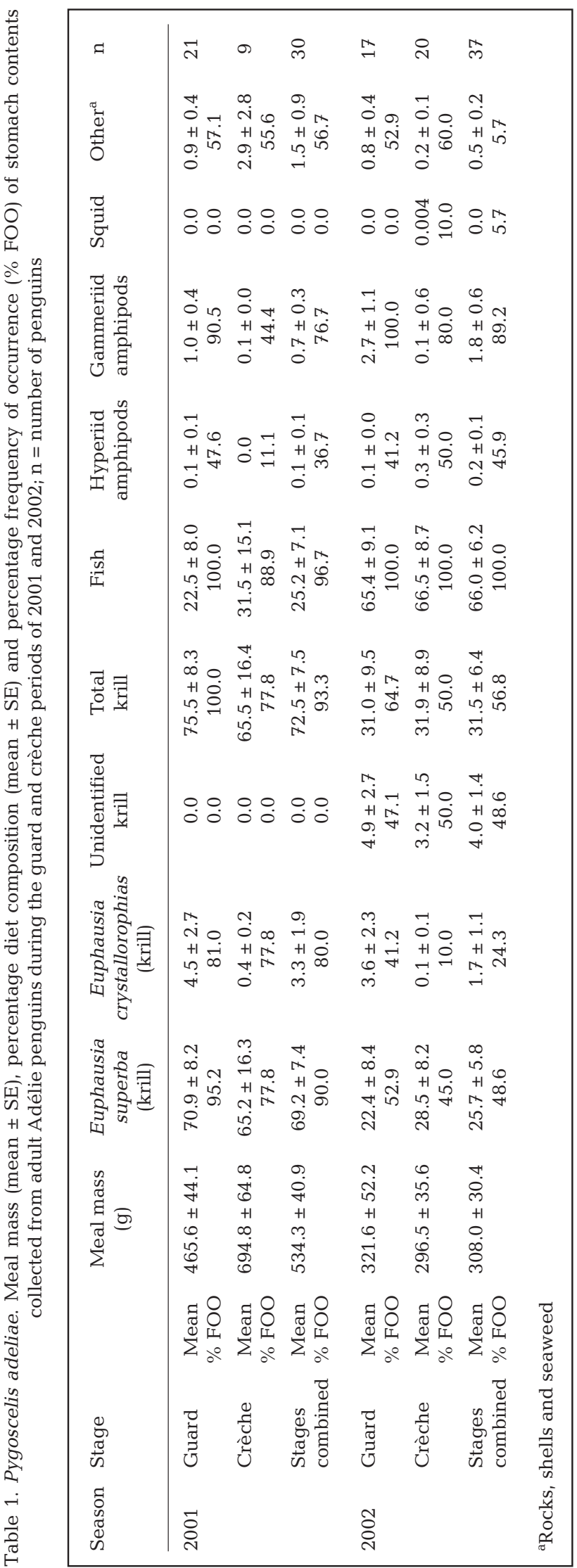

\section{Diet composition of chicks determined from SIA and stomach content analysis}

With regard to the $\delta^{13} \mathrm{C}$ and $\delta^{15} \mathrm{~N}$ signatures of prey items, mean $\pm \mathrm{SD} \delta^{13} \mathrm{C}$ and $\delta^{15} \mathrm{~N}$ values of 9 whole, lipid-free adult Euphausia superba were $-24.79 \pm 0.86$ and $3.01 \pm 0.77 \%$, respectively. Mean $\pm \mathrm{SD} \delta^{13} \mathrm{C}$ and $\delta^{15} \mathrm{~N}$ values of 10 whole, lipid-free juvenile Trematomus newnesi were $-19.96 \pm 1.10$ and $8.99 \pm 0.90 \%$, respectively.

The proportional estimates of the 2 major items contributing to chick diet (krill and fish) calculated from SIA and stomach content analysis did not differ (2001: $t=2.08, \mathrm{df}=19, \mathrm{p}=0.32 ; 2002: t=2.07, \mathrm{df}=19, \mathrm{p}=$ $0.17)$. Both methods estimated that chick diet was dominated by krill in the 2001 crèche period and by fish in 2002 (Fig. 1).

\section{Comparison of $\delta^{13} \mathrm{C}$ and $\delta^{15} \mathrm{~N}$ signatures and diet composition of adults and chicks}

Mean $\pm \mathrm{SD} \delta^{13} \mathrm{C}$ and $\delta^{15} \mathrm{~N}$ signatures in the blood of adults and chicks during crèche are presented in Table 2. For $\delta^{13} \mathrm{C}$ values, there was no interaction between year and age $\left(F_{1,60}=0.0007, \mathrm{p}=0.98\right)$, but there was evidence of an age effect, with adult blood more depleted in $\delta^{13} \mathrm{C}$ compared with chicks $\left(F_{1,60}=\right.$ 9.33, $\mathrm{p}=0.04$; means \pm SD for adults and chicks, pooled across years were $-25.57 \pm 0.72 \%$ and $-25.06 \pm 0.61 \%$, respectively). There was also moderate evidence of a

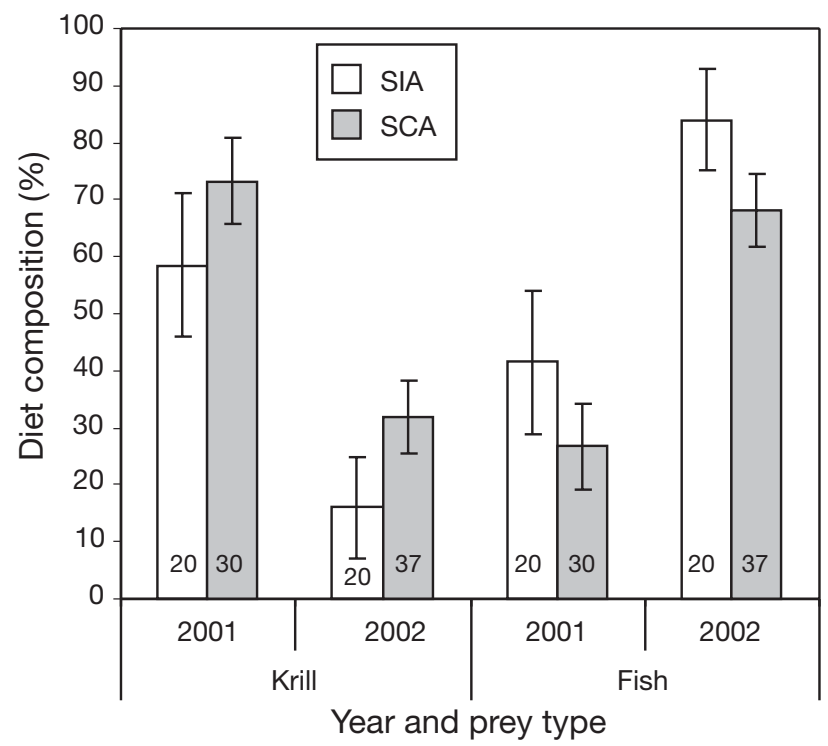

Fig. 1. Pygoscelis adeliae. Proportion (mean \pm SE) of krill and fish in the diet of Adélie penguin chicks during the crèche period over 2 consecutive summers (2001 and 2002) using stable-isotope (SIA) and stomach content analysis (SCA). Sample sizes (number of penguins) shown inside the bars 
Table 2. Pygoscelis adeliae. $\delta^{13} \mathrm{C}$ and $\delta^{15} \mathrm{~N}$ signatures (means $\pm \mathrm{SD}$ and range, \%) for adult and chick Adélie penguin blood and feathers sampled during different stages of the breeding and moulting periods over consecutive summers; $\mathrm{n}=$ number of penguins

\begin{tabular}{|c|c|c|c|c|c|c|c|c|}
\hline Year & Age & Stage & Tissue type & $\delta^{13} \mathrm{C}$ & Range $\delta^{13} \mathrm{C}$ & $\delta^{15} \mathrm{~N}$ & Range $\delta^{15} \mathrm{~N}$ & $\mathrm{n}$ \\
\hline 2000 & Adults & Moult & Feathers & $-26.7 \pm 0.5$ & -27.2 to -25.5 & $9.4 \pm 1.2$ & 7.7 to 14.1 & 31 \\
\hline \multirow[t]{6}{*}{2001} & Adults & Arrival & Blood & $-28.1 \pm 0.4$ & -29.1 to -27.6 & $9.0 \pm 2.2$ & 5.1 to 13.1 & 22 \\
\hline & & Incubation & Blood & $-26.7 \pm 0.5$ & -27.4 to -25.7 & $7.5 \pm 1.0$ & 4.9 to 9.1 & 11 \\
\hline & & Guard & Blood & $-26.5 \pm 0.3$ & -26.8 to -26.1 & $7.6 \pm 3.2$ & 3.6 to 12.1 & 7 \\
\hline & & Crèche & Blood & $-25.7 \pm 0.7$ & -26.4 to -24.1 & $6.9 \pm 2.9$ & 1.4 to 11.4 & 16 \\
\hline & & Moult & Feathers & $-25.7 \pm 0.3$ & -26.6 to -25.1 & $7.8 \pm 2.8$ & 1.7 to 9.7 & 30 \\
\hline & Chicks & Crèche & Blood & $-25.2 \pm 0.5$ & -26.0 to -24.1 & $8.2 \pm 3.2$ & 2.9 to 12.7 & 20 \\
\hline \multirow[t]{6}{*}{2002} & Adults & Arrival & Blood & $-27.3 \pm 0.6$ & -27.7 to -26.7 & $7.3 \pm 0.7$ & 6.9 to 8.2 & 3 \\
\hline & & Incubation & Blood & $-26.9 \pm 0.2$ & -27.2 to -26.8 & $7.2 \pm 0.1$ & 7.1 to 7.3 & 3 \\
\hline & & Guard & Blood & $-26.3 \pm 0.5$ & -26.7 to -25.5 & $10.0 \pm 2.5$ & 7.3 to 12.8 & 5 \\
\hline & & Crèche & Blood & $-25.4 \pm 0.8$ & -26.1 to -23.6 & $11.5 \pm 1.5$ & 8.6 to 13.8 & 8 \\
\hline & & Moult & Feathers & $-26.0 \pm 0.5$ & -26.9 to -25.0 & $9.2 \pm 1.8$ & 6.9 to 14.8 & 31 \\
\hline & Chicks & Crèche & Blood & $-24.9 \pm 0.7$ & -26.4 to -23.9 & $10.7 \pm 2.1$ & 6.8 to 14.3 & 20 \\
\hline
\end{tabular}

year effect, where the $\delta^{13} \mathrm{C}$ ratios of both adults and chicks were more depleted in 2002 compared with $2001\left(F_{1,60}=3.68, \mathrm{p}=0.06\right.$; means $\pm \mathrm{SD}$ for adults and chicks, pooled across ages, were $-25.42 \pm 0.62 \%$ and $-25.03 \pm 0.73 \%$, respectively). There was no interaction between age and year $\left(F_{1,60}=2.08, \mathrm{p}=0.15\right)$ and no age effect in $\delta^{15} \mathrm{~N}$ signatures $\left(F_{1,60}=2.12, \mathrm{p}=0.15\right)$. There was strong evidence for a year effect, with blood $\delta^{15} \mathrm{~N}$ signatures of both adults and chicks significantly more enriched in the 2002 crèche period $\left(F_{1,60}=22.94\right.$, $\mathrm{p}<0.0001$; means \pm SD for 2001 and 2002, pooled across ages, were $7.63 \pm 3.10 \%$ ond $10.96 \pm 1.99$, respectively). Diet composition of adults and chicks during crèche, calculated by the isotopic mixing model, was substantially different between the 2 years,

Table 3. Pygoscelis adeliae. Proportion of krill in the diet of adult and chick Adélie penguins during different stages of breeding and moulting periods over consecutive summers determined from a 2-source isotope mixing model. Lower and upper $95 \%$ confidence limits shown in parentheses; $\mathrm{n}=$ number of penguins

\begin{tabular}{|c|c|c|c|c|}
\hline Year & Age & Stage & $\begin{array}{c}\text { Krill } \\
\text { Mean composition (\%) }\end{array}$ & $\mathrm{n}$ \\
\hline 2000 & Adults & Moult & $64.2(54.6-73.8)$ & 31 \\
\hline \multirow[t]{6}{*}{2001} & Adults & Arrival & $45.7(28.0-63.3)$ & 22 \\
\hline & & Incubation & $69.4(56.3-82.5)$ & 11 \\
\hline & & Guard & 68.7 (19.0-100) & 7 \\
\hline & & Crèche & $79.8(53.4-100)$ & 16 \\
\hline & & Moult & $90.577 .4-100)$ & 30 \\
\hline & Chicks & Crèche & $58.5(32.5-84.6)$ & 20 \\
\hline \multirow[t]{6}{*}{2002} & Adults & Arrival & $72.7(48.1-97.3)$ & 3 \\
\hline & & Incubation & $74.8(66.8-82.7)$ & 3 \\
\hline & & Guard & $27.8(0.0-80.2)$ & 5 \\
\hline & & Crèche & $2.7(0.0-17.0)$ & 8 \\
\hline & & Moult & $67.4(54.8-80.0)$ & 31 \\
\hline & Chicks & Crèche & $16.1(0.0-34.4)$ & 20 \\
\hline
\end{tabular}

with krill comprising a higher proportion of their diet in 2001, while fish dominated in 2002 (Table 3).

\section{Intra- and inter-annual $\delta^{13} \mathrm{C}$ and $\delta^{15} \mathrm{~N}$ signatures and diet composition of adults}

Mean $\delta^{13} \mathrm{C}$ blood isotope signatures ranged from -28.09 to $-25.36 \%$, and $\delta^{13} \mathrm{C}$ feather isotope signatures ranged between -26.66 and $-25.73 \%$ (Table 2 ). There was no interaction between year and age in $\delta^{13} \mathrm{C}$ signatures of the blood $\left(F_{3,67}=1.56, \mathrm{p}=0.21\right)$ but there was strong evidence that $\delta^{13} \mathrm{C}$ signatures differed between stages $\left(F_{3,67}=84.00, \mathrm{p}<0.0001\right)$, with more depleted $\delta^{13} \mathrm{C}$ values during arrival and more enriched $\delta^{13} \mathrm{C}$ signatures during crèche (Tukey's HSD, all $\mathrm{p}<0.001$ ). The $\delta^{13} \mathrm{C}$ isotope signatures from incubation and guard blood samples fell between these extremes (Tukey's HSD, $p=0.14$; Fig. 2). There was also some evidence of

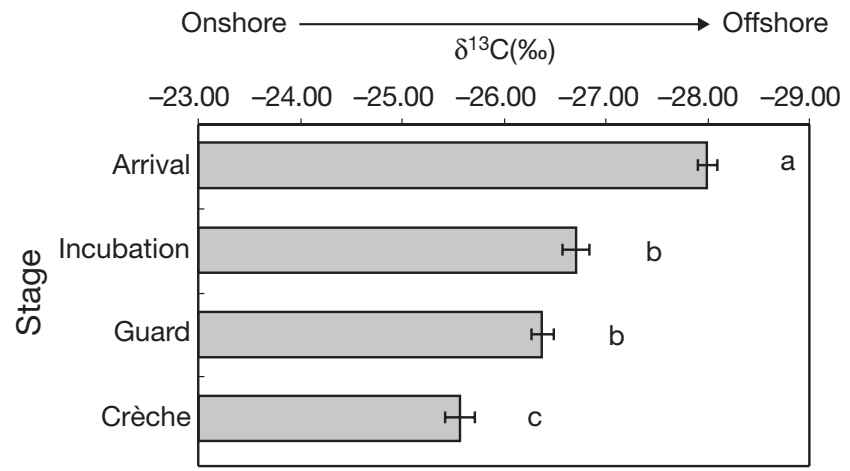

Fig. 2. Pygoscelis adeliae. $\delta^{13} \mathrm{C}$ signatures of adult Adélie penguin blood (means $\pm \mathrm{SE}$ ) in each breeding stage. Data pooled across 2001 and 2002 samples for each period. More negative $\delta^{13} \mathrm{C}$ values indicate foraging offshore. a-c denote significant differences from post-hoc Tukey's HSD tests 
a year effect, with $\delta^{13} \mathrm{C}$ signatures more depleted in 2001 than $2002\left(F_{1,67}=3.34, \mathrm{p}=0.07\right.$; means $\pm \mathrm{SD}$ for 2001 and 2002, pooled across stages, were $-26.91 \pm$ $1.13 \%$ and $-26.15 \pm 0.98 \%$, respectively). Mean feather $\delta^{13} \mathrm{C}$ values of the 2000 moult period were considerably more depleted than those from 2001 and $2002\left(F_{1,90}=29.12, \mathrm{p}<0.0001\right.$; Table 2$)$. Mean $\delta^{15} \mathrm{~N}$ blood-isotope signatures of adults ranged from 6.92 to $11.53 \%$, and mean $\delta^{15} \mathrm{~N}$ feather signatures ranged between 7.78 and $9.35 \%$ o (Table 2). There was a strong interaction effect between year and stages $\left(F_{3,67}=5.48\right.$, $\mathrm{p}=0.002$ ), with more enriched $\delta^{15} \mathrm{~N}$ signatures in the blood during the guard and crèche periods in the 2002 season (Fig. 3). Feather $\delta^{15} \mathrm{~N}$ signatures did not vary between moult years $\left(F_{1,90}=0.19, \mathrm{p}=0.67\right.$; Table 2$)$.

The mixing model estimated that adult birds consumed progressively more krill as the season advanced in 2001, including the pre-moult foraging trip. During 2002, however, their diet was more variable. They predominately ate krill during the early part of the season, temporarily switched and consumed mostly fish during the chick rearing period, and then reverted to krill during the pre-moult foraging period. It appears that krill also dominated their diet during the pre-moult trip in 2000 (Table 3).

\section{DISCUSSION}

Knowledge of the spatial and temporal variability of the diet of top predators such as seabirds contributes to the understanding of marine ecosystem dynamics and may be used in models for evaluating impacts of ecological variation or formulating management policies for conservation or fisheries practises (Barrett et al. 1990, Bost \& le Maho 1993, Quillfeldt et al. 2005). However, direct dietary techniques often have biases asso-

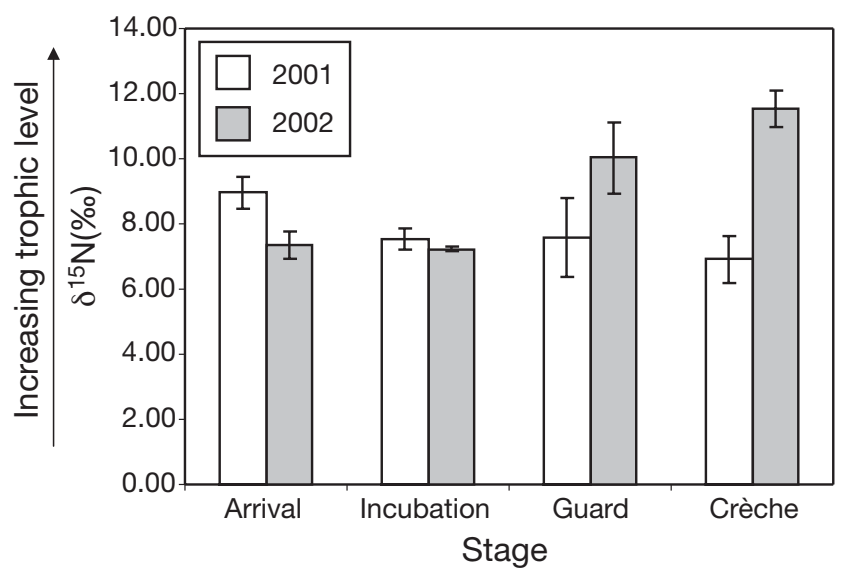

Fig. 3. Pygoscelis adeliae. $\delta^{15} \mathrm{~N}$ signatures of adult Adélie penguin blood (means \pm SE) sampled in each stage of 2001 and 2002, showing interaction effect ciated with them that limit their usefulness. Our results indicate that SIA describes trends in diet composition similar to those determined from stomach content analysis. Further, although adult and chick diet composition did not differ, the $\delta^{13} \mathrm{C}$ signatures suggest that adults obtained prey for their chicks closer inshore than prey used for self-feeding. The composition of adult diet and broad foraging areas also varied both intra- and inter-annually, which may have consequences for the way Adélie penguin diet is monitored for ecosystem management.

\section{Diet composition of chicks determined by SIA and stomach content analysis}

The diet composition of Adélie penguin chicks determined using SIA of their blood closely reflected that determined from stomach contents of adults sampled at the same time. The isotopic mixing model estimated that there was $\sim 15 \%$ less krill and $\sim 15 \%$ more fish compared with estimates based on stomach contents. It should be noted, though, that fish in stomachs are often so well digested that some is inadvertently lost through the sieves during the sorting stage; hence, the proportion of fish in the diet calculated from stomach content analysis may often be underestimated. Regardless, the temporal trends between the 2 techniques were consistent, indicating that both methods reflect 'real' dietary signals over time. In the absence of being able to ground truth Adélie penguin diet in the wild, it is encouraging that the conclusions drawn by both methods concur, despite their associated biases and limitations. Similarly, Ainley et al. (2003) found that the diet of Adélie penguins in the Ross sea area as determined by isotopic analysis of chick toenails reflected the diet determined from adult stomach contents. Although SIA did not provide the same taxonomic resolution as stomach content analysis, the ability to detect shifts in the major prey items consumed by predators may be of an adequate level of resolution for many monitoring programmes.

\section{Diet composition and feeding ecology of adults and chicks during crèche}

Several seabird studies using SIA have shown that diet composition can differ substantially between adults and their dependent chicks (Hobson 1993, Hodum \& Hobson 2000, Forero et al. 2002). In some cases, adults preferentially fed their chicks fish rather than invertebrates such as krill or squid. Compared with these items, fish provide higher caloric content at lower foraging costs, are easier and faster to digest, 
have lower salt loads, and promote growth due to their higher calorific, protein and calcium levels (Hodum \& Hobson 2000, Forero et al. 2002, Ainley et al. 2003).

We did not find any differences between the blood $\delta^{15} \mathrm{~N}$ signatures of adult Adélie penguins and their chicks, suggesting there is no trophic segregation in their diets, although finer-scale differences (such as Euphausia superba vs. Euphausia crystallorophias) cannot be ruled out. The mixing model also estimated that their diets consisted of similar proportions of krill and fish. Further, we only compared the diets of adult and chicks during the later stages of the chick-rearing (crèche) period. Energetic requirements for growth and development of Adélie penguin chicks during crèche means they require large, though less frequent, meals than when they first hatch (Salihoglu et al. 2001). Therefore, during crèche, adults may concentrate their foraging efforts on the most abundant prey at the time, regardless of its nutritive value, in order to provision chicks with a meal of adequate size, and to sustain themselves. Evidence for this may come from the $\delta^{13} \mathrm{C}$ and $\delta^{15} \mathrm{~N}$ values of adults and chicks in each year. Their depleted $\delta^{13} \mathrm{C}$ in 2001 indicates that adults were likely foraging offshore. Their low $\delta^{15} \mathrm{~N}$ values indicate they were likely consuming resources from the lower trophic levels, which the isotopic mixing model predicted to be krill. By comparison, the elevated $\delta^{13} \mathrm{C}$ in 2002 points to more onshore foraging, and the higher $\delta^{15} \mathrm{~N}$ signatures indicate they were consuming higher trophic level prey, predicted to be fish. This data corresponds with the known distribution of Antarctic krill and notothenid fish. E. superba are typically found just offshore of the continental shelf break, which lies $\sim 120 \mathrm{~km}$ off the Mawson coast, in waters $\geq 2000 \mathrm{~m}$ deep (Nicol et al. 2006), while juvenile Trematomus newnesi are typically found in the shallower, nearshore shelf waters (Gon \& Heemstra 1990). Pleuragramma antarcticum, another notothenid fish commonly consumed by Adélie penguins (Clarke et al. 1998) with a $\delta^{15} \mathrm{~N}$ signature similar to T. newnesi (Hodum \& Hobson 2000), also occurs in the shelf waters 400 to $500 \mathrm{~m}$ deep (Gon \& Heemstra 1990). However, we should add a caveat here that we cannot automatically assume that these penguins were also consuming $P$. antarcticum just because they have a $\delta^{15} \mathrm{~N}$ signature similar to $T$. newnesi. A difference in the $\delta^{13} \mathrm{C}$ values for these species (compare this study with Hodum \& Hobson 2000 and references therein) indicates that they may belong to different ecosystems with different baseline $\delta^{15} \mathrm{~N}$ levels, and hence, may preclude a direct comparison between them.

$\delta^{13} \mathrm{C}$ signatures did differ between adults and chicks, with those of adults more depleted than those of chicks in 2001 and 2002. This suggests that adults may start to digest and assimilate prey caught furthest from the colony for themselves, while the more enriched $\delta^{13} \mathrm{C}$ signatures of chicks suggests they are fed prey that is caught closer to shore, presumably on the return leg of the parents' foraging trip. Magellanic penguins showed similar, but opposite, patterns, with adults foraging for themselves close to shore on poorer quality food, while making longer offshore trips to collect food of higher quality for their chicks (Forero et al. 2002). Forero et al. (2002) suggest that separating food intake times is the only way these birds can segregate food for self-maintenance and offspring provisioning, and this may be the case for Adélie penguins.

\section{Intra- and inter-annual diet and foraging ecology of adults}

Due to temporal limitations in the practical application of sampling stomach contents of seabirds, there is a major gap in the knowledge of adult Adélie penguin diet outside of the chick-rearing period. We found that SIA could provide diet data for adult Adélie penguins for various stages of their annual cycle and that their diet varied both intra- and inter-annually. The temporal differences in Adélie $\delta^{13} \mathrm{C}$ and $\delta^{15} \mathrm{~N}$ signatures likely reflect the foraging limitations placed on them by factors including sea-ice extent, their obligation to provision offspring, the need to maintain their own body condition and the abundance and distribution of prey (Clarke et al. 2006 and references therein).

Blood $\delta^{13} \mathrm{C}$ signatures were constant between years but varied between stages. Prior to the start of the breeding season, the Antarctic fast ice is at both its maximum extent and concentration, preventing penguins from foraging close to shore. Consequently, we observed the most depleted $\delta^{13} \mathrm{C}$ levels (which reflect offshore foraging) in those birds sampled as they arrived back at the breeding colonies. The incubation and guard $\delta^{13} \mathrm{C}$ values were more enriched than during arrival but more depleted than those from crèche. While it makes intuitive sense that adult birds would be foraging closer to shore during crèche compared with incubation due to sea-ice extent, satellite tracks of Adélies from the Mawson region show that birds actually appear to forage closest to shore during the guard period (Clarke et al. 2006). Guard stage $\delta^{13} \mathrm{C}$ may have been more depleted than the values from crèche, even though they were probably foraging closer to shore, because it is unlikely that they were feeding for themselves during this time, instead concentrating foraging efforts on provisioning chicks by making frequent, short trips from the colony (Clarke et al. 2006). Therefore, bloods we sampled during guard may have had a remanent $\delta^{13} \mathrm{C}$ signature from feeding during the incubation period, which could also explain why there was 
no difference between the guard and incubation $\delta^{13} \mathrm{C}$ blood values. To examine the potential overlap between signatures of the guard and crèche period, we may need to make a closer examination of isotopic turnover times in whole blood. Carleton \& del Rio (2005) suggest that $\delta^{13} \mathrm{C}$ half-lives can be estimated from body mass. When we examined their data, which was compiled from relatively light birds compared with the mass of penguins, we found this relationship to be poor. However, we may be better able to understand and interpret our $\delta^{13} \mathrm{C}$ data if we calculate the half-life of $\delta^{13} \mathrm{C}$ in penguins directly.

It should also be noted that the change in $\delta^{13} \mathrm{C}$ signatures we observed between stages may not reflect just the change between onshore and offshore foraging. It is possible that the primary prey items came from benthic vs. pelagic food webs and/or that the amount of ice-related algae in the diet of their prey changed, which would alter the $\delta^{13} \mathrm{C}$ signal (Kelly 2000). Both scenarios are possible, considering the seasonal changes to sea-ice extent and concentration, which would alter the availability of different foraging habitat to penguins and their prey.

Blood $\delta^{15} \mathrm{~N}$ signatures differed both intra- and interannually. Mid-level $\delta^{15} \mathrm{~N}$ signatures indicate that during the last stages of their winter foraging and during the incubation trips, adult penguins were consuming a mixture of krill and fish in both 2001 and 2002, although greater proportions of krill were consumed in 2002. $\delta^{15} \mathrm{~N}$ values in the guard and crèche periods were more variable. In 2001, the proportion of krill in the diet increased as the season progressed into the chickrearing period. In 2002, however, there was a noticeable shift from krill in the first part of the season to fish in the guard and crèche periods. Ship-board acoustic surveys carried out during the 2002 chick-rearing period detected a low abundance of krill in the penguins' foraging grounds (Nicol et al. 2006), which may explain why the birds switched from krill to fish. Other possible explanations for the switch may include intraspecific interference competition for krill resources with neighbouring colonies (Ainley et al. 2004), competition with other top predators (Ainley et al. 2006) or the decrease of sea-ice cover, which provides habitat for Antarctic krill (Ainley et al. 2003).

Clarke et al. (2006) provide some information on where Adélie penguins forage during their pre-moult foraging trips; however, prior to this study, virtually nothing was known about their diet during this period. The more depleted feather $\delta^{13} \mathrm{C}$ signatures from 2000 indicate that the birds were foraging farther offshore than they did in 2001 or 2002 . The difference between years is likely related to the variable distribution of their prey at this time of year (Clarke et al. 2006 and references therein). The feather $\delta^{15} \mathrm{~N}$ signatures did not vary between the 3 years analysed and indicated that they predominately ate krill. It should be noted that a recent study by Cherel et al. (2005a) supports the hypothesis that amino acids required for keratin synthesis of feathers comes from both dietary proteins obtained while penguins are at sea feeding prior to the moult and from endogenous reserves used during the moulting fast (Cherel et al. 1994). Because fasting can elevate $\delta^{15} \mathrm{~N}$ levels, these authors (op. cit.) suggest that care should be taken in the interpretation of feeding ecology derived from feather $\delta^{15} \mathrm{~N}$ signatures. It is therefore possible that the $\delta^{15} \mathrm{~N}$ signatures observed in Adélie feathers in this study could in reality be lower, which would mean krill probably featured even more predominantly in their pre-moult diet than what we have depicted here.

\section{Implications for monitoring and management}

Maximum sea-ice extent varies spatially and temporally around the Antarctic continent, and therefore, commercial fishing vessels can operate at different times of the year in different regions of the Southern Ocean. In East Antarctica, ice-free periods when fishing could take place extend from late summer though to mid-autumn. Penguin foraging ranges overlap with historical fishing grounds for Antarctic krill in the Mawson region of East Antarctica (Kerry et al. 1997). Therefore, the most immediate impact from commercial fishing on Adélie penguins in this area could be during both the late chick rearing and pre-moult periods, i.e. times when these birds are highly dependent on resources, such as krill, for provisioning chicks and accumulating energy reserves for their upcoming moult. However, these periods do not completely overlap with the time that it is possible to collect samples for conventional dietary analysis. The variability observed in diet composition and foraging ecology of adult penguins over the breeding and moulting periods, as revealed by SIA in this study, also shows that extrapolations of data from stomach contents during periods outside of chick-rearing could be incorrect.

SIA may provide a means for augmenting diet data collected by direct methods. It is logistically simpler to collect large sample numbers, which promotes the possibility of conducting much broader, regional surveys of diet much more efficiently (e.g. Ainley et al. 2003). Collection of blood and tissue samples can be considered less invasive than collecting stomach samples; given that handling times are reduced, there is less potential for injury to the bird, and chicks are not denied a meal. Consequently, SIA may be seen as more ethically acceptable if large sample numbers are required. And, importantly, SIA also provides a means 
for extending the temporal window for obtaining the relevant information required for modelling and management protocols, particularly during those times which are most critical for assessing the effects of commercial fishing on the Southern Ocean ecosystem. Further investigations should be made into whether other tissues, such as bird claws, which have shown potential for use in stable-isotope analysis (Ainley et al. 2003) could be used to gain an indication of diet over the winter period, as demonstrated for sub-Antarctic penguins (Cherel et al. 2007), and/or whether blood plasma (which has a faster isotopic turnover compared with whole blood) could reveal more fine-scale foraging habits of Adélie penguins.

Acknowledgements. We thank L. Irvine, L. Meyer, R. Pike, K. Newberry and all members of the 54th, 55th and 56th ANARE expeditions for assistance in the field; $\mathrm{S}$. Candy for assistance with statistical analyses; D. Wagner and M. Baker, and technical officers at Metabolic Solutions for analysing all stable isotope samples; and to A. Constable, S. Jarman and 3 anonymous referees who gave valuable comments on earlier drafts of this manuscript. Funding was provided by grants from the Australian Antarctic Program (AAP), project \#2205 and \#2301, and by a University of Tasmania (UTAS) Post-graduate Research Scholarship and an Antarctic Climate and Ecosystems Cooperative Research Centres (ACE-CRC) Scholarship awarded to M.T. All procedures were approved by both the AAP and UTAS Animal Ethics Committees.

\section{LITERATURE CITED}

Ainley D (2002) The Adelie penguin: bellwether of climate change. Columbia University Press, New York

Ainley D, Ballard G, Barton KJ, Karl B, Rau GH, Ribic CA, Wilson PR (2003) Spatial and temporal variation of diet within a presumed metapopulation of Adelie penguins. Condor 105:95-106

Ainley DG, Ribic CA, Ballard G, Heath S and others (2004) Geographic structure of Adelie penguin populations: overlap in colony-specific foraging areas. Ecol Monogr 74: $159-178$

Ainley DG, Ballard G, Dugger KM (2006) Competition among penguins and cetaceans reveals trophic cascades in the western Ross Sea, Antarctica. Ecology 87:2080-2093

Barrett RT, Rov N, Loen J, Montevecchi WA (1990) Diets of shags Phalacrocorax aristotelis and cormorants $P$. carbo in Norway and possible implications for gadoid stock recruitment. Mar Ecol Prog Ser 66:205-218

Bearhop S, Waldron S, Votier SC, Furness RW (2002) Factors that influence assimilation rates and fractionation of nitrogen and carbon stable isotopes in avian blood and feathers. Physiol Biochem Zool 75:451-458

Berrow SD, Croxall JP (1999) The diet of white-chinned petrels Procellaria aequinoctialis, Linnaeus 1758, in years of contrasting prey availability at South Georgia. Antarct Sci 11: 283-292

Bost CA, le Maho Y (1993) Seabirds as bio-indicators of changing marine ecosystems: new perspectives. Acta Ecol 14: 463-470

Carleton S, de Rio C (2005) The effect of cold-induced increased metabolic rate on the rate of ${ }^{13} \mathrm{C}$ and ${ }^{15} \mathrm{~N}$ incorpo- ration in house sparrows (Passer domesticus). Oecologia 144:226-232

Cherel Y, Hobson KA (2007) Geographical variation in carbon stable isotope signatures of marine predators: a tool to investigate their foraging areas in the Southern Ocean. Mar Ecol Prog Ser 329:281-287

Cherel Y, Charrassin JB, Challet E (1994) Energy and protein requirements for molt in the king penguin Aptenodytes patagonicus. Am J Physiol 266:R1182-R1188

Cherel Y, Hobson KA, Bailleul F, Groscolas R (2005a) Nutrition, physiology, and stable isotopes: new information from fasting and molting penguins. Ecology 86:2881-2888

Cherel Y, Hobson KA, Hassani S (2005b) Isotopic discrimination between food and blood and feathers of captive penguins: implications for dietary studies in the wild. Physiol Biochem Zool 78:106-115

Cherel Y, Hobson KA, Guinet C, Vanpe C (2007) Stable isotopes document seasonal changes in trophic niches and winter foraging individual specialization in diving predators from the Southern Ocean. J Anim Ecology 76:826-836

Clarke J, Manly B, Kerry K, Gardner H, Franchi E, Corsolini S, Focardi S (1998) Sex differences in Adélie penguin foraging strategies. Polar Biol 20:248-258

Clarke J, Emmerson L, Otahal P (2006) Environmental conditions and life history constraints determine foraging range in breeding Adélie penguins. Mar Ecol Prog Ser 310: $247-261$

Constable AJ, de la Mare WK, Agnew DJ, Everson I, Miller D (2000) Managing fisheries to conserve the Antarctic marine ecosystem: practical implementation of the Convention on the Conservation of Antarctic Marine Living Resources (CCAMLR). ICES J Mar Sci 57:778-791

DeNiro MJ, Epstein S (1978) Influence of diet on the distribution of carbon isotopes in animals. Geochim Cosmochim Acta 42:495-506

DeNiro MJ, Epstein S (1981) Influence of diet on the distribution of nitrogen isotopes in animals. Geochim Cosmochim Acta 45:341-351

Forero MG, Hobson KA, Bortolotti GR, Donázar JA, Bertellotti M, Blanco G (2002) Food resource utilisation by the Magellanic penguin evaluated through stable-isotope analysis: segregation by sex and age and influence on offspring quality. Mar Ecol Prog Ser 234:289-299

Furness BL, Laugksch RC, Duffy DC (1984) Cephalopod beaks and studies of seabird diets. Auk 101:619-620

Gon O, Heemstra PC (1990) Fishes of the Southern Ocean. JLB Smith Institute of Ichthyology, Grahamstown, South Africa

Hobson KA (1993) Trophic relationships among high Arctic seabirds: insights from tissue-dependent stable-isotope models. Mar Ecol Prog Ser 95:7-18

Hobson KA, Clark RG (1992a) Assessing avian diets using stable isotopes I: turnover of ${ }^{13} \mathrm{C}$ in tissues. Condor 94: 181-188

Hobson KA, Clark RG (1992b) Assessing avian diets using stable isotopes II: factors influencing diet-tissue fractionation. Condor 94:189-197

Hobson KA, Clark RG (1993) Turnover of ${ }^{13} \mathrm{C}$ in cellular and plasma fractions of blood: implications for non-destructive sampling in avian dietary studies. Auk 110:638-644

Hobson KA, Welch HE (1992) Determination of trophic relationships within a high Arctic marine food web using $\delta^{13} \mathrm{C}$ and $\delta^{15} \mathrm{~N}$ analysis. Mar Ecol Prog Ser 84:9-18

Hodum PJ, Hobson KA (2000) Trophic relationships among Antarctic fulmarine petrels: insights into dietary overlap and chick provisioning strategies inferred from stableisotope $\left(\delta^{15} \mathrm{~N}\right.$ and $\left.\delta^{13} \mathrm{C}\right)$ analyses. Mar Ecol Prog Ser 198: $273-281$ 
Kelly JF (2000) Stable isotopes of carbon and nitrogen in the study of avian and mammalian trophic ecology. Can J Zool 78:1-27

Kerry K, Clarke J, Eberhard S, Gardner H, Lawless R, Tremont $R$, Wienecke B (1997) The foraging range of Adélie penguins - implications for CEMP and interactions with the krill fishery. CCAMLR Sci 4:75-87

Klasing KC (1998) Comparative avian nutrition. CAB International, New York

McCutchan JH, Lewis WM, Kendall C, McGrath CC (2003) Variation in trophic shift for stable isotope ratios of carbon, nitrogen, and sulfur. Oikos 102:378-390

Michener RH, Schell DM (1994) Stable isotope ratios as tracers in marine aquatic food webs. In: Lajtha $\mathrm{K}$, Michener RH (eds) Stable isotopes in ecology and environmental science. Blackwell Scientific Publications, London, p 138-157

Nagy KA (1987) Field metabolic rate and food requirement scaling in mammals and birds. Ecol Monogr 57:111-128

Nicol S, Clarke J, Romaine SJ, Kawaguchi S, Williams G, Hosie GW (2008) Krill (Euphausia superba) abundance and Adélie penguin (Pygoscelis adeliae) breeding performance in the waters off the Béchervaise Island colony, East Antarctica in two years with contrasting ecological conditions. Deep-Sea Res II (in press)

Owens NJP (1987) Natural variations in ${ }^{15} \mathrm{~N}$ in the marine environment. Adv Mar Biol 24:389-451

Pauly T, Nicol S, Higginbottom I, Hosie G, Kitchener J (2000) Distribution and abundance of Antarctic krill (Euphausia

Editorial responsibility: Otto Kinne,

Oldendorf/Luhe, Germany superba) off East Antarctica $\left(80-150^{\circ} \mathrm{E}\right)$ during the austral summer of 1995/1996. Deep Sea Res 47:2465-2488

Payne RW (2002) The guide to GenStat ${ }^{\circledR}$ Release 6.1. Part 2: Statistics. VSN International, Oxford

Phillips DL, Gregg JW (2001) Uncertainty in source partitioning using stable isotopes. Oecologia 127:171-179

Quillfeldt P, McGill RAR, Furness RW (2005) Diet and foraging areas of Southern Ocean seabirds and their prey inferred from stable isotopes: review and case study of Wilson's storm-petrel. Mar Ecol Prog Ser 295:295-304

Salihoglu B, Fraser WR, Hofmann EE (2001) Factors affecting fledging weight of Adelie penguin (Pygoscelis adeliae) chicks: a modeling study. Polar Biol 24:328-337

SC-CAMLR (Scientific Committee for the Conservation of Antarctic Marine Living Resources) (1997) CCAMLR ecosystem monitoring program: standard methods for monitoring studies. CCAMLR, Hobart

Steel RGD, Torrie JH (1960) Principles and Procedures of Statistics. McGraw-Hill, New York

Steel WK (2005) Stable isotope ratios of Antarctic petrel (Thalassoica antarctica) and snow petrel (Pagadroma nivea) bone collagen. Polar Biol 28:672-697

Thompson DR, Furness RW (1995) Stable-isotope ratios of carbon and nitrogen in feathers indicate seasonal dietary shifts in northern fulmars. Auk 112:493-498

Wilson RP (1984) An improved stomach pump for penguins and other seabirds. J Field Ornithol 55:109-112

Zar JH (1996) Biostatistical Analysis, 3rd edn. Prentice-Hall, Upper Saddle River, NJ

Submitted: October 24, 2006; Accepted: August 31, 2007

Proofs received from author(s): February 4, 2008 